\title{
Managed aquifer recharge (MAR): the relationship between surface water temperature in recharge basin and groundwater temperature - The case of the Rokugo alluvial fan, in northern Japan
}

\author{
Noboru HIDA *1 and Makoto KAGABU *2
}

\begin{abstract}
In this paper, the authors consider the relationship between surface water temperature in a basin of managed aquifer recharge (MAR) and the groundwater temperature in the case of the Rokugo alluvial fan, in northern Japan. The results show water temperature of basin No.2, installed in the center of the fan, has an influence on the shallow groundwater temperature at the observation well which is next to the basin. Under the condition of about $60 \mathrm{~L} / \mathrm{sec}$ water supply to basin No.2, water temperature inside basin No.2 does not have an influence on groundwater temperature at the Nonaka piezometer at depths of $20 \mathrm{~m}$ and $50 \mathrm{~m}$ which is $274 \mathrm{~m}$ away from the center of the basin. This study is continued more in future, while increasing water supplies to the basin.
\end{abstract}

Key words: managed aquifer recharge (MAR), groundwater temperature, snowfall, paddy fields, alluvial fan

\section{Purpose}

First, the authors would like to find what kind of influence the water temperature of the No.2 MAR (managed aquifer recharge) basin, constructed at the center of the Rokugo alluvial fan (Hida, 2007), had on the shallow groundwater temperature under the basin. Second, they would like to find what kind of influence the water temperature of the No.2 MAR basin had on groundwater temperature at the Nonaka piezometer which is $274 \mathrm{~m}$ away from the center of the MAR basin and is 4 meters lower than the site of the basin site.

On completing this paper, the authors referred to the suggestive articles (Arai and Yokohata, 1990; Domonico and Palciauskas, 1973;
Fujii, 2002; Hantke, 1981; Kagabu, 2007; Shimano and Taniguchi, 2006; Uchida and Sakura, 2007).

II. Hydrological face (Hida, 2007, p.297)

The Rokugo alluvial fan lies around $39^{\circ} 25^{\prime} \mathrm{N}$ and $140^{\circ} 34^{\prime} \mathrm{E}$ in northern Japan.

The distance between the proximal fan, at 90 meters above sea level, and the distal fan, at 45 meters, is about four kilometers (Fig. 1).

The unconfined aquifer of the Rorugo alluvial fan consists mainly of gravel, which has a hydraulic conductivity of $10^{\circ} \sim 10^{-2} \mathrm{~cm} / \mathrm{sec}$ and specific yield over $20 \%$. The depth of the aquifer is over 100 meters around the center of the fan. Annual mean precipitation is $1,653 \mathrm{~mm}$ and annual

* 1 Professor Emeritus, Akita University, Japan

* 2 Graduated School of Science and Technology, Kumamoto University, Japan 
mean potential evapotranspiration is estimated at $660 \mathrm{~mm}$. Maximum snow depth occurs during a period from mid-January to mid-February. It averages $130 \mathrm{~cm}$ in the distal fan and $150 \mathrm{~cm}$ in the proximal fan.

The annual groundwater level changes regularly. The level is high during the period of paddy field irrigation from May to August and low during the non-irrigation period. As for land use, the paddy fields account for 70 per cent of the total surface of the fan.

\section{The MAR basin No.2 and Observation Instruments (Hida and Ohizumi (Ohta), 2005)}

\section{The MAR basin No.2}

Four MAR basins (Nos.1 - 4) are installed at the fan (Fig. 1). This paper is focused on basin No. 2., the biggest one of the four basins.

Basin No. 2 is set up in the center of the fan $\left(39^{\circ} 25^{\prime} 00^{\prime \prime} \mathrm{N}, 140^{\circ} 34^{\prime} 05^{\prime \prime} \mathrm{E}\right.$, Elevation of $\left.68.0 \mathrm{~m}\right)$. It was founded in 1992 and was expanded in 1994, and the total area of the basin bed is 2,120 square meters. The basin bed is dug $3.4 \mathrm{~m}$ below the land surface. The four sides and the bed of the basin are in an unlined form, and the gravel layer of the alluvial fan crops out. The materials which cause clogging, such as silt and clay, which accumulate on the basin bed are carried out removing with dump trucks once every autumn.

The source water supplying the basin uses the irrigation canal water, which is taken from the Maruko river. Average water supply is about $60 \mathrm{~L} / \mathrm{sec}$. Water temperature is between $2-3$ degrees Celsius in January-February and about 30 degrees Celsius in August.

\section{Observation Instruments}

The water temperature logger in the basin : A

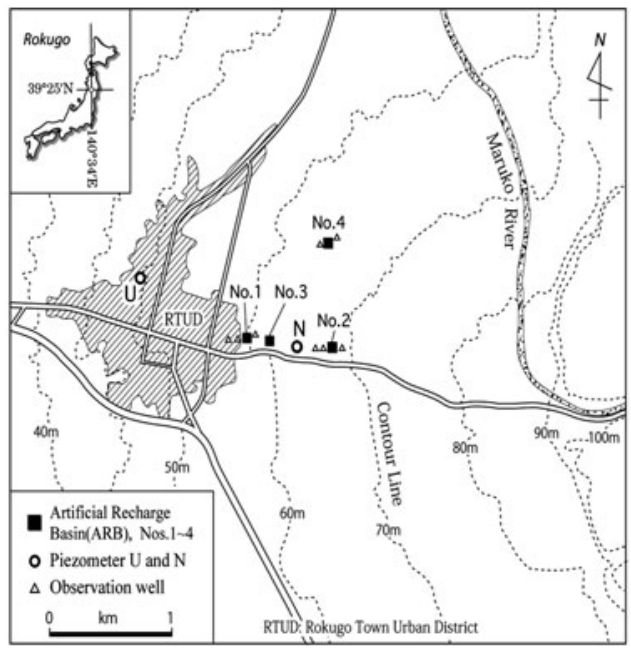

Fig. 1 Study area of the Rokugo alluvial fan, MAR basins and observation instruments

water temperature logger was installed 3 centimeters over the basin bed in October, 2006 (Fig. 2, Photo 1). The data is recorded every 10 minutes at the site of the observation well mentioned below.

Observation well: Groundwater temperature and hydraulic head under the basin No.2 were recorded every 10 minutes by using an observation well which is $5.45 \mathrm{~m}$ from the western hedge of the basin (Fig. 2, Photo 1). As for the depth, the well is $15.05 \mathrm{~m}$ and a $4.0 \mathrm{~m}$ screen is set at the well bottom. Water temperature and hydraulic head sensors are at the bottom end of the well. The geological structure to $15.05 \mathrm{~m}$ consists of alluvial sand and gravel (Hida and Ohizumi (Ohta), 2005, p.33). The water table appears at a depth of 7-8 meters from the land surface.

Piezometer (Fig. 1): Piezometer nests were constructed in 1991 at Nonaka (39 $25^{\prime} 02^{\prime \prime} \mathrm{N}, 140^{\circ}$ $33^{\prime} 55^{\prime \prime} \mathrm{E}$ and Elv. of $64.19 \mathrm{~m}$ ) in the center of the Rokugo alluvial fan and at Umamachi $\left(39^{\circ} 25^{\prime} 18^{\prime \prime}\right.$ $\mathrm{N}, 140^{\circ} 33^{\prime} 03^{\prime \prime} \mathrm{E}$ and Elv. of $48.37 \mathrm{~m}$ ) in the distal fan. In this paper, the records of $20 \mathrm{~m}$ depth piezometer at Nonaka are used. A screen of $2 \mathrm{~m}$ 


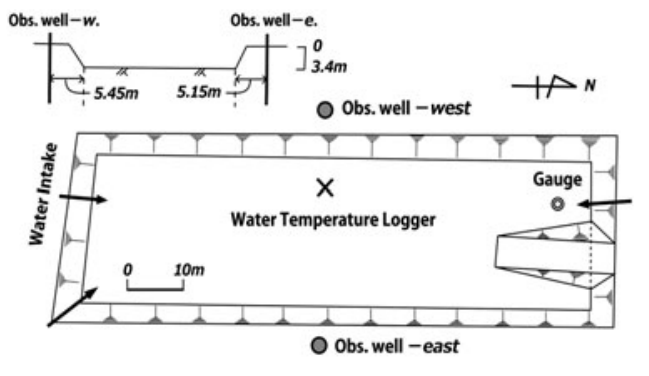

Fig. 2 The MAR basin No.2, water temperature logger and observation well

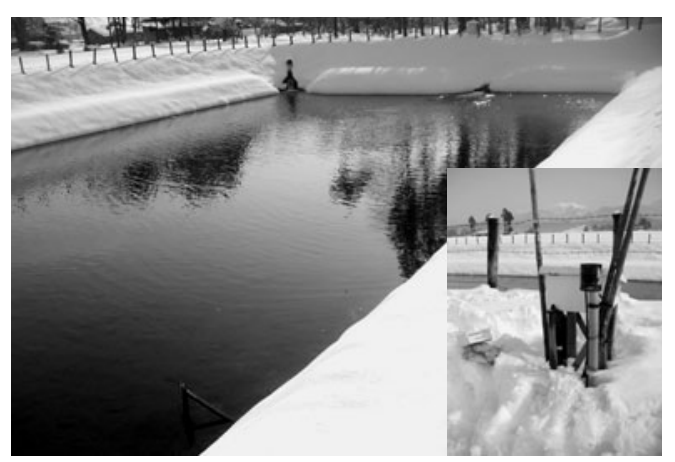

Photo 1 The MAR basin No.2, a water temperature logger (lower part of the photo) and an observation well at the $5.45 \mathrm{~m}$ from the western hedge of the basin, Jan 07, 2008

was set at the bottom, and the both sensors of water temperature and hydraulic head was put in the bottom. Nonaka nests is $274 \mathrm{~m}$ away from the center of the MAR basin. The geological structure to $20 \mathrm{~m}$ mainly consists of alluvial sand and gravel (Hida, 2007, p.300). Recording interval here is every 10 minutes as well as basin No.2. In addition, precipitation is observed at the Nonaka piezometer station.

\section{Results}

Thime (1898), Dortmunder Stadtwerke AG (1966) and Schmidt (1995) already pointed out importance regarding the following consideration in the case of basin artificial recharge.
Here the authors deal with the records from October $6^{\text {th }} 2006$ until the time in August 2008. Data was recorded every 10 minutes with a digital data recoder (NDR model) at the western hedge of basin No. 2 (Fig. 2) and at the Nonaka piezometer.

1. What kind of influence does the water temperature of basin No.2 have on the shallow groundwater temperature under the basin?

Water supply to basin No. 2 was started on the morning of October $7^{\text {th }}, 2006$ and continued until August 2008. Groundwater level rose at the observation well at the western hedge of basin No. 2 about two hours after beginning the water supply. At that time, a groundwater mound was formed under the bottom of the basin (Hida and Ohizumi, 2006). And, a rise of groundwater temperature appeared from the evening of October $8^{\text {th }}$ at the same observation well.

Water temperature inside basin No. 2 was the lowest in February and highest in August, 2007 and June, 2008. The lowest temperature was approximately $2^{\circ} \mathrm{C}$, and the highest temperatures were approximately $30^{\circ} \mathrm{C}$ in 2007 and $24^{\circ} \mathrm{C}$ in 2008 . Daily variation of water temperature was observed throughout the year (Fig. 3).

Groundwater temperature shown as legend No.2 in Fig. 3 was low in the winter season and high in the summer season. In the case of the winter season from 2006 to 2007, the lowest water temperature appeared in February at approximately $5{ }^{\circ} \mathrm{C}$ and the highest water temperature in the summer season of 2007 appeared in July at approximately $16{ }^{\circ} \mathrm{C}$. Furthermore in the case of 2008 , the lowest water temperature, approx-imately $4{ }^{\circ} \mathrm{C}$, appeared in March and the highest water temperature, approximately $19^{\circ} \mathrm{C}$, appeared in August.

Groundwater temperature at the observation well at the western hedge of basin No.2 responded 


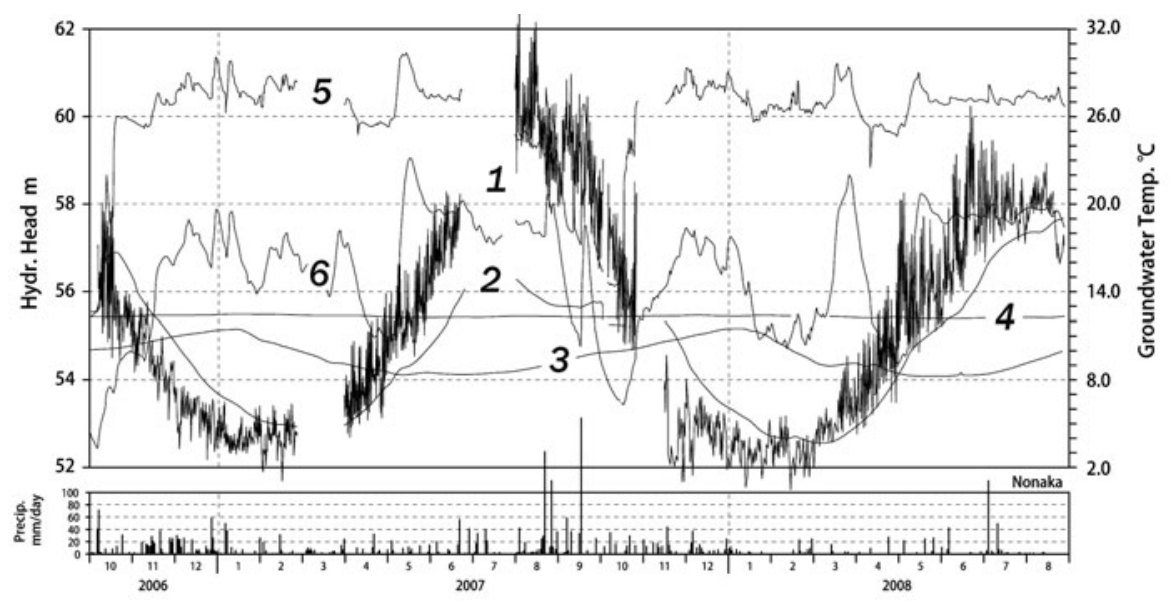

LEGEND 1: Water temperature inside basin No. 2, 2: groundwater temperature of the observation well at the western hedge of basin No. 2, 3 and 4: groundwater temperature of at the Nonaka piezometer at depths of $20 \mathrm{~m}(3)$ and $50 \mathrm{~m}(4), 5$ and 6 : hydraulic head of the observation well at the western hedge of basin No. 2(5) and of at the Nonaka piezometer at depth of $20 \mathrm{~m}$ (6)

Fig. 3 Water temperature inside basin No. 2, groundwater temperature and hydraulic head of the observation well at the western hedge of the basin and groundwater temperature and hydraulic head of at the Nonaka piezometer at depths of $20 \mathrm{~m}$ and 50m, October 2006-August 2008

almost corres- pondingly to the annual change of the water temperature inside the basin No.2. The monthly average water temperature of basin No.2 (x) and the monthly average groundwater temperature of the observation well (y) shows a considerably high correlation such that

$$
y=0.4935 x+4.4933, R^{2}=0.6553 \quad \text { (Fig. 4). }
$$

Clearly, water temperature of basin No.2 has an influence on the groundwater temperature at the observation well.

There is no significant correlation between the fluctuation of the hydraulic head shown as legend No. 5 in Fig. 3 and the fluctuation of groundwater temperature shown as legend No.2 in Fig. 3 at the observation well. The relationship of the monthly average hydraulic head (x) and monthly average groundwater temperature (y) at the observation well from October 2006 to August 2008 is as shown:

$$
\mathrm{y}=-1.6701 \mathrm{x}+110.46, \mathrm{R}^{2}=0.1312 .
$$

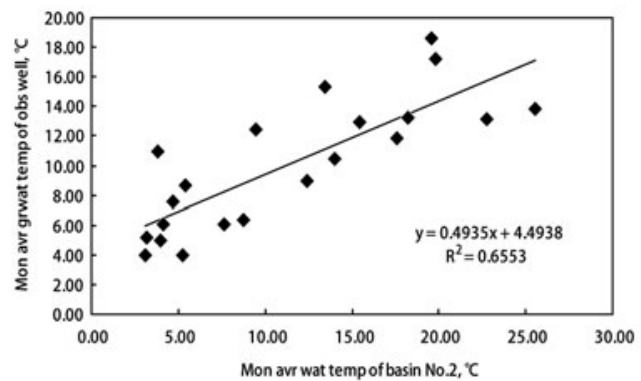

Fig. 4 Correlation of the monthly average water temperature of basin No.2 (x) and the monthly average groundwater temperature of the observation well (y), October 2006August 2008

(Here, the data of two months of March and July, 2007 are missing.)

2. What kind of influence does the water temperature of basin No.2 have on groundwater temperature at the piezometer at Nonaka at a depth of $20 \mathrm{~m}$ ?

A correlation is not observed between the time series changes of the groundwater temperature 
at the piezometer at Nonaka at a depth of $20 \mathrm{~m}$ and the time series changes of the water temperature inside basin No.2.

An approximation formula:

$$
\mathrm{y}=-0.0556 \mathrm{x}+10.365, \mathrm{R}^{2}=0.1287
$$

is shown in correlation of the monthly average water temperature inside basin No.2 (x) and the monthly average groundwater temperature at the piezometer at Nonaka at a depth of $20 \mathrm{~m}$ (y) from October 2006 to August 2008. Under the condition of about 60L/sec water supply to basin No.2, water temperature inside basin No.2 has an influence on groundwater temperature in the piezometer at Nonaka at depth of $20 \mathrm{~m}$ with retardation in phase and reduction in amplitude due to convective groundwater flow (Arai and Yokota, 1990), but mostly no influence on groundwater temperature in the piezometer at depth of $50 \mathrm{~m}$. It may be said that the water recharged from basin No.2 joins with the existing groundwater which flows into the aquifer from the basin to the piezometer at Nonaka.

Additionally, as for cold water at the time of the melting snow supplied to basin No.2, the records show that the action temporarily lowers the groundwater temperature at the piezometer at Nonaka at a depth of $20 \mathrm{~m}$. Kagabu (2007, p.4) showed the diffusion of groundwater temperature in the shallow aquifer under basin No.2. The observation of these matters will continue under the operation of basin No.2.

The hydraulic head at the observation well is higher than the hydraulic head at the piezometer at Nonaka at a depth of $20 \mathrm{~m}$, and this latter value is higher than the hydraulic head at the piezometer at Nonaka at a depth of $50 \mathrm{~m}$. During the period, the water level in basin No.2 changed about $64.94-65.04 \mathrm{~m}$ in elevation. Correlation of the monthly average hydraulic head at a depth of

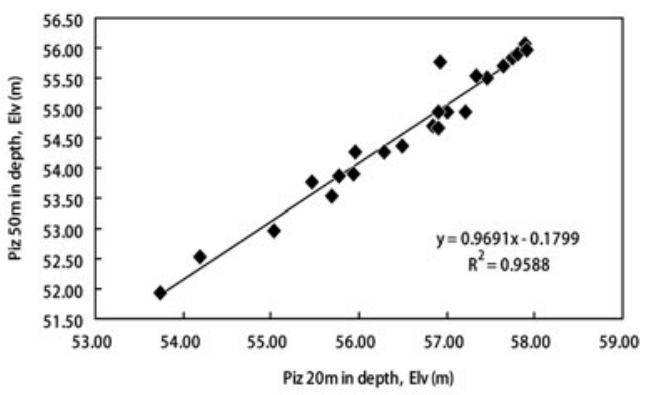

Fig. 5 Correlation of monthly average hydraulic head at a depth of $20 \mathrm{~m}$ (x) and at a depth of $50 \mathrm{~m}$ (y) at the piezometer at Nonaka, October 2006-August 2008

$20 \mathrm{~m}$ (x) and at a depth of $50 \mathrm{~m}$ (y) at the piezometer at Nonaka from October 2006 to August 2008 is shown as follows:

$\mathrm{y}=0.9691 \mathrm{x}-0.1799, \mathrm{R}^{2}=0.9583$ (Fig. 5).

Clearly, the groundwater is recharged in and around basin No.2, and moves toward the deeper direction.

The observed result regarding the vertical distribution of groundwater temperature at the Nonaka 50m depth piezometer by Kagabu (2007, p.5) supports that the site of the piezometer, almost in the center of the fan including basin No.2, is the recharge area for the groundwater, which is pointed out according to Demonico and Palciauskas (1973). Considerations regards to this theme will be added more in the coming days.

\section{Concluding remarks}

The relationship between surface water temperature in an artificial basin and groundwater temperature are summarized as mentioned above by using the observation records from October 2006 until the time in August 2008.

Based on these results, the authors will consider the followings: first, how the existing groundwater temperature changes by increasing the quantity of water to basin No.2. And second, how strategic 
methods devise to use melting snow water as the source for MAR using the basin method in the snow area. To be concrete, the authors have a plan to melt snow on the roof of the house and the lifeline road in the eastern region of basin No.2 by using pumped groundwater (about $13{ }^{\circ} \mathrm{C}$ ), and to reuse the groundwater and the melting snow water in total as the source of basin No.2. This is a next stage study, including a sociological solution of issues regarding the aging society.

\section{Acknowledgement}

This study is supported by Grant-in-Aid for Exploratory Research of the Japanese Ministry of ESSC, No.18650265 in 2006-2008, and JSPS Grantin-Aid for Scientific Research (B), No.19401002 in 2007-2010.

\section{References}

Arai, T. and Yokohata, M. (1990): Temperature and flow of groundwater in Egawa region, Tokushima prefecture, Japan. Geogr. Rewiew of Japan, 63A, 343-355. (in Japanese with English abstract)

Demonico, P. A. and Palciauskas, V. V. (1973): Theoretical analysis of forced convective heat transfer in regional groundwater flow. Geol. Soci. of Amer. Bull., 84, 3803-3814.

Dortmunder Stadtwerke AG (1966): Die kuenstliche Grundwasseranreicherung. Veroefft. der DS-AG, Nr.9, Dortmund, 196s. (in Germany)

Fujii, H. (2002): A study on completion and configuration of heat exchange wells in groundcoupled heat pump systems with groundwater flow. J. Geotherm. Res. Soc. Japan, 24, 191-205. (in Japanese with English abstract)

Hantke, H. (1981): Vergleichende Bewertung von Anlagen zur Grundwasseranreicherung. Schriftenreihe WAR 6, Darmstadt, 368s. (in Germany)
Hida, N. (2007): An overview of experiences of basin artificial recharge of groundwater in Japan. J. Jap. Assoc. Hydrol. Sci., 37, 295-302.

Hida, N. and Ohizumi (Ohta), Y. (2005): Basin artificial recharge of groundwater in the Rokugo alluvial fan, northern Japan. Memoirs of Faculty of EHS, Akita Univ. (Human. \& Social Scinc.), 60, 29-39.

Hida,N. and Ohizumi,Y. (2006): Basin artificial recharge and groundwater mound formation: A case of the Rokugo alluvial aquifer, northern Japan. Luck, F. et al., Orgs. Recharge systems for protecting and enhancing groundwater resources, IHP-VI, Series on Groundwater No.13, UNESCO, 687-692.

Kagabu, M. (2007): Correspondence of groundwater temperature with artificial recharge in Rokugo alluvial fan, Akita Prefecture. Gegr. Review of Akita University, 54, 1-6. (in Japanese)

Schmidt, W.-D. (1995): Zur Anwendung der kuensliche Grundwasseranreicherung in Deutchland. DVGWSchreiftenreihe, Wasser, Nr.85, 7-28. (in Germany) Shimano, Y. and Taniguchi, M. (2006): Groundwater flow analysis using the groundwater temperature in the Imaichi depositional fan, Tochigi prefecture. Bunsei Kiyou, Bunsei Univ., 17, 29-88. (in Japanese) Thime, A.(1898): Die kuenstliche Erzeung von Grundwasser. GWF-Wasser/Abwasser, 41, 207212. (in Germany)

Uchida, Y. and Sakura, Y. (2007): Present state of study on subsurface temperature and contribution of hydrology on it. J. Jap. Assoc. Hydrol. Sci., 37, 253-269. (in Japanese with English abstract)

（受付：2008年12月17日）

(受理：2009年 3 月10日）

この論文に対する「討論」を2009年10月31日ま で受け付けます。 